\title{
Socio-economic and Environmental Sustainability of Ecotourism Implementation: A Study in Ubud Monkey Forest-Bali, Indonesia
}

\author{
Omar Sambou ${ }^{1 *}$, Harsuko Riniwati ${ }^{2}$, Zaenal Fanani ${ }^{2}$ \\ ${ }^{1}$ Master Program of Environmental Resource Management and Development, University of Brawijaya, Malang, \\ Indonesia \\ 2Postgraduate School, University of Brawijaya, Malang, Indonesia
}

\begin{abstract}
Ecotourism is the fastest growing sector in the global tourism industry and provides for environmental conservation, socio-economic development, cultural preservation, employment and empowerment of indigenous people of ecotourism destinations. This study seeks to find the socio-economic and environmental sustainability of ecotourism practices in Ubud Monkey Forest-Bali under the three dimensions of sustainable development; economic progress, environmental protection and conservation, and socio-cultural preservation. Both quantitative and qualitative research methodologies used with the following conduct: (1) Questionnaire administration, (2) Interviews, and (3) Observations. Data was analized using Content Analysis and Multidimensional scaling (MDS) techniques to describe: (1) the susainabiliti of ecotourism in Is ecotourism in Ubud Monkey Forest (2) sustainability index of each of the dimensions under study in Ubud Monkey Forest, and (3) describes the level of sensitivity of sustainability of each dimension in Ubud Monkey Forest. The Kite Diagram of Sustainability Analysis presents that the sustainability status of all the used dimension which classified as sustain. The overall sustainability status of ecotourism is sustainable with an index of 76.49. The most sustainable dimension is education and recreation, while the least is the participation dimension. It shows that the dimensions under study support sustainability in ecotourism. The results of this study confirmed that within the parameters of the study, the forest maintained an ecological balance, socio-economic advancement, and cultural preservation. Ecotourism has high attraction potentials for both tourist and local businesses while impacting less on the culture, environment and the traditional practices of the Balinese people. Notwithstanding, there is a general problem of land-use change and waste management in Bali.
\end{abstract}

Keywords: Ecotourism, Environment, Monkey Forest, Socio-economic, Sustainability.

\section{INTRODUCTION}

Tourism is continuously seen as a basic instrument in progressing economic development, alleviating poverty, and advancing food security [1]. There are different attraction factors to tourist visits in every destination. It is widely believed that modern-day tourism is increasing in politically stable countries with a rich culture, beautiful nature, and biodiversity, which is referred as ecotourism. Exploring local people's contributions to ecotourism destinations should be a prerequisite for sustainable tourism, particularly if the destination's characteristics are associated with local culture and tradition [2].

Bali is a tropical island in Indonesia famous for tourism due to its beautiful nature, green vegetation mountains, beaches, coral reefs, and rice production, etc. With its exceptional natural sites and indigenous cultures, Indonesia could

\footnotetext{
* Correspondence Address:

Omar Sambou

E-mail : osambou@utg.edu.gm

Address : Postgraduate School, University of Brawijaya JI. MT. Haryono 169, Malang 65145
}

become one of the world leaders in ecotourism, with Bali playing a key role.

The role of the indigenous people in maintaining the island in a way that attracts tourists and also enables them to carry out their socio-economic activities and agricultural practices is of great importance and pivotal in the quest for sustainable ecotourism and human development in the area. Cultural landscapes that link human and natural systems are not only places of natural beauty but also provide background information about the history of human adaptations to nature but also provide background information about the history of human adaptations to nature [3].

Bali is chosen for this research as it is the biggest/highest tourist destination In Indonesia and metaphorically referred to as the Paradise on Earth. The research intends to find out; (1) the susainabiliti of ecotourism in Is ecotourism in Ubud Monkey Forest (2) sustainability index of each of the dimensions under study in Ubud Monkey Forest, and (3) describes the level of sensitivity of sustainability of each dimension in Ubud Monkey Forest.

This paper highlight the existing trend in the practice of ecotourism towards sustainable development and economic growth in Bali by; (1) 
analyzing the index of sustainability of each dimension understudy on the ecotourism site, (2) analyze the sensitivity of sustainability of each dimension in Ubud Monkey Forest, and (3) analysis to improve the sustainability of each dimension understudy in Ubud Monkey Forest.

\section{MATERIAL AND METHOD Study Area}

Bali Island is situated east of Java and the west of the Lesser Sunda Islands in the Indonesia archipelago. The island covers an area of $5,632.86 \mathrm{~km}^{2}$ and is the primary home of the Hindu community in Indonesia [3]. Ubud Monkey Forest is located in Padangtegal Village. It has spiritual connections as well as nature conservation and socio-economic activities through tourism. It has a total land area of 12.5 hectares, and according to the staff, it's a habitat for approximately 700 crab-eating macaques (Macaca fascicularis) commonly called the Monkey Temple.

\section{Method and Analysis}

In this study, exploratory research applied to deeply explore the topic from the perspective of sustainable development under three areas of interest; Environment, Economic progress, and social equity through a Descriptive Qualitative Research Method. However, the quantitative method was used due to the nature of the topic, and the combination of these two methods in research is called a Mixed Method. Content Analysis and Multidimensional Scaling (MDS) were used in the date analysis to know the sustainability status of the forest.

\section{Data Collection}

Mixed methods research focuses on collecting, analyzing, and mixing both quantitative and qualitative data in a single study or series of studies. Data was collected through purposive sampling using observations, questionnaires, and interviews.

Observation: Non-verbal observation was done on the site based on the interest of the research, online observation of reviewers, and rates of the forest. Personal observations on the site include the activities on the site, tourist and nature interaction, and available sustainability programs. Reviews and ratings on the website of the forest were used to acquire information or data.

Questionnaire: They are used to know the level of sustainability of ecotourism, its problems, and the attraction potentials. Sixty (60) questionnaires were administered in the forest and the surrounding environment. The forest employees, tourists, elderly farmers, businessmen, tourist taxi drivers, and tour guides were respondents to the questionnaires. The questionnaire is about the sustainability index and the level of sensitivity of sustainability under five (5) dimensions namely Conservation, Participation, Education and Recreation, Economy, and Control.

Interviews: Employees of the forest, close business owners, tourist taxi drivers, elderly farmers, and tourists were interviewed, and a general opinion of people about the forest were sought out of casual discussions.

\section{RESULT AND DISCUSSION}

Nature destruction is a threat to sustainable tourism in a destination. Therefore tourism development must include the environment as part of tourism resources that need to be developed in terms of quality and its variety [4].

Ubud Monkey Forest is considered to be one of the most famous parks in Bali and has over the years been visited by thousands of tourists. The park welcomes approximately 10,000 tourists every month. Over 30,000 visitors reviewed their experience in the park, and 20,236 people rated the site. The following information acquired from the internet (Table 1).

Table 1. Rating by Visitors

\begin{tabular}{|c|c|c|}
\hline Rating & No. of People & Percentage \\
\hline Excellent & 9,412 & 47 \\
\hline Very Good & 7387 & 37 \\
\hline Average & 2582 & 13 \\
\hline Poor & 481 & 2 \\
\hline Terrible & 374 & 1 \\
\hline Total & 20,236 & 100 \\
\hline
\end{tabular}

The above table indicated that $97 \%$ of the ratings are within the acceptable satisfaction of the visitors. Total $47 \%$ of the visitors rated the forest as excellent, $37 \%$ rated as Very Good, while $13 \%$ rated it as average. The above can be considered as acceptable satisfaction whereas $2 \%$ rated it as bad and $1 \%$ as terrible.

The park maintains a good management practice and visitor satisfaction from a management point based on the ratings. Acceptably, the park has registered an improved socio-economic advancement both for staff and community through its attraction factors. It 
attracts tourists and small businesses within the area, thereby improving the income level of the locals while maintaining an ecological balance within the park and providing high visitor (tourist) satisfaction. The randomly picked reviewed comments indicated that most of the visitors have a positive impression on the park which means that the park is properly managed and nature is maintained.

\section{Questionnaire}

A questionnaire was administered on the research site and surrounding businesses to people with some understanding of the subject matter. The total number of respondents is 60 , in which $39(65 \%)$ of them are males, and 21 (35\%) are female. A total of 50 respondents are native Indonesian Balinese, which represents $83.3 \%$ of the total respondents, and ten tourists representing $16.7 \%$, among whom four are male and six are female. Among the native Indonesian Balinese, 35 are male, and 15 are female. A total of $12(20 \%)$ are employees of the park, 11 (18.3\%) are local businessmen, 10 (16.7\%) are elderly (farmers), 9 (15\%) are tour guides, and 8 (13.3\%) taxi drivers.

Table 2 : Characteristics of Respondents

\begin{tabular}{lcc}
\hline Description & No. of People & Percentage \\
\hline Park Employees & 12 & 20.0 \\
Businessmen & 11 & 18.3 \\
Tourist & 10 & 16.7 \\
The eldery (farmers) & 10 & 16.7 \\
Tour Guide & 9 & 15.0 \\
Tourist Taxi Drivers & 8 & 13.3 \\
\hline \multicolumn{1}{c}{ Total } & 60 & 100 \\
\hline
\end{tabular}

Sources: Primary Data obtained, 2019

\section{MDS Rapfish Results Analysis}

The result of goodness-of-fit calculation for MDS-Rapfish analysis is displayed in Table 3 . According to Table 3, the S-Stress value of the four dimensions is less than 0.25 , and the $\mathrm{R}$ squares are more than 0.90 . It means that the result of MDS-Rapfish analysis can be accounted for or veritable. Since the criteria for goodnessof-fit fulfilled, then the analysis to assess sustainability status for each dimension can be carried.

Table 3. Summary Goodness-of-fit MDS-Rapfish Analysis

\begin{tabular}{lrr}
\hline Dimension & Stress (S) & R-Square (R) \\
\hline Conservation & 0.2267 & 0.9262 \\
Participation & 0.2081 & 0.9262 \\
Education and recreation & 0.2304 & 0.9379 \\
Economy & 0.2353 & 0.9195 \\
Control & 0.2430 & 0.9055 \\
\hline
\end{tabular}

Source: Add-ins Ms. Excel Rapfish, 2019

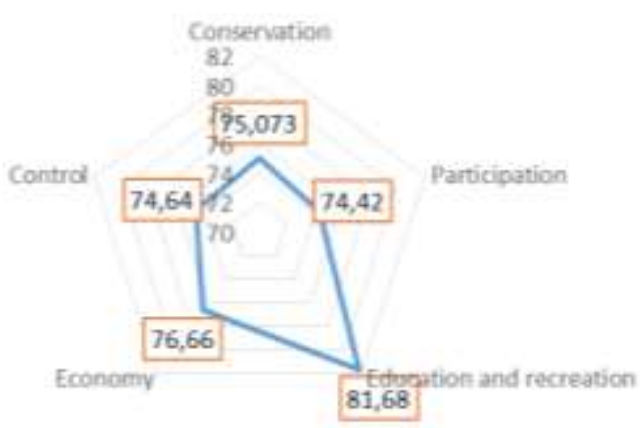

Figure 1. Kite Diagram of Sustainability Analysis Sources: Primary Data Processed, 2019

Figure 1 presents the sustainability status of all the used dimension classified as sustain. The overall sustainability status of ecotourism is sustainable, with the index as many as 76.49 . The most sustainable dimension is education and recreation, while the least is the participation dimension. The maximum attainable figure is 100 , which is the highest level of sustainability. The higher the figure, indicates the higher the rate of sustainability, and the lower the figure, indicates lower the sustainability.

\section{Interview}

The information of the respondent is presented as follows. GW is an employee of the Monkey forest as a security guard for many years. The following information was acquired willingly from him.

"Environmental conservation and management is a key component of any sustainable development quest including sustainable ecological tourism, which cannot be attain without the participation of local communities".

Joint management of natural resources between a community and tour operator can offer a means of sustainable utilising resources [5]. Ceding of authority to a local community and allowing its members to decide how local resources are used, can be a powerful incentive to alter behaviour towards conservation and thereby protection of natural resources.

At the Ubud Monkey forest, the Tri Hita Karana concept is used to manage the park. It is a Balinese doctrine which values the existence of God and reconciles the environment and society for a sustainable livelihood without destruction. Ecotourism has been proposed as a viable economic activity that can minimize negative human impacts on wildlife habitat and provide an 
incentive to preserve natural areas. The potential of ecotourism as a wildlife conservation strategy is limited by its inability to ensure the long-term protection of environmental assets and by its tendency to contribute directly to environmental degradation [6].

Economically, the forest employs many people directly and indirectly. Many businesses around the park are established because of the high tourist attraction potential of the park. Local people are employed, and they earn a good living from the existence of the forest. Many direct and indirect jobs are created; tour guides, tourist taxi drivers, local businesses, restaurants, homestay apartments, hotels, etc. Yet, these activities are not completely positive as land-use changes while other members of society are involved in other activites as ecotourism is an expensive venture. In practice, ecotourism has often failed to deliver the expected benefits to indigenous communities due to a combination of factors, including shortages in the endowments of human, financial and social capital within the community, lack of mechanisms for a fair distribution of the economic benefits of ecotourism, and land insecurity [7].

Bali is a Hindu dominant province of Indonesia, where over $80 \%$ of the people are Hindu in a Muslim dominated country. WWF [8] believe that there is an enormous common ground between the attitudes of faith towards the environment and the current international efforts to complete a global, ecologicallyrepresentative protected area network. Both are rooted in a shared ethical view that humans have an obligation to avoid destroying the rest of biodiversity through their actions, and both are based on the concept of setting aside areas of land and water to facilitate the conservation of wild nature.

Tourism has contributed significantly to the economic and social advancement of the people of Bali but has also contributed negatively to their cultural values and lifestyles a little. Youngsters copy some western lifestyles, but dominantly, our cultural values are highly respected and maintained. The employees of the forest dress in a traditional outfit to promote our culture.

In summary, the interviews conducted conclude that the activities of the Balinese towards sustainability is not by chance, but it is principally part of their religion and culture. There is a general problem of waste management, which is not due to ecotourism, although generally linked to tourism. While ecotourism attracts businesses that were lead to land-use change in the area.

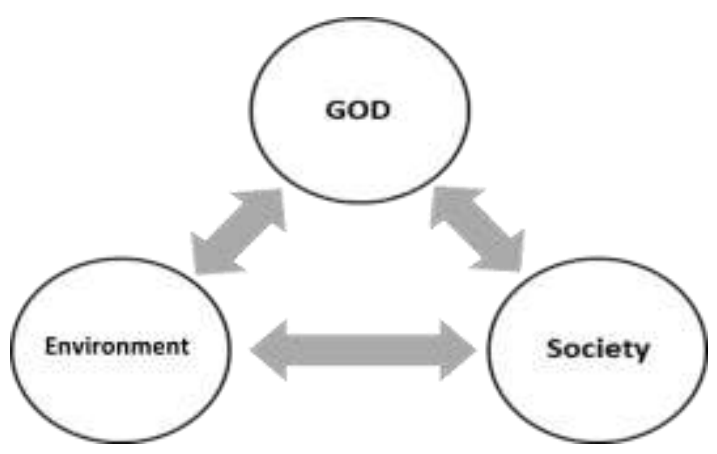

Figure 2. Illustration of the Tri Hita Karana Doctrine Source: Illustration by author, 2019

\section{CONCLUSION}

Ecotourism is considered to be the fastest growing sector in the global tourism industry. It has the potentials to protect and conserve the environment, promote the economic development of local people, bring infrastructural development, and promote the culture and tradition of local people of ecotourism destinations. The Balinese doctrine Tri Hita Karana is very essential for the quest for sustainable ecotourism in Bali. It has inculcated a sense of responsibility and common concern in the Hindu people of Bali in their quest for sustainable development.

The Ubud Monkey Forest is a sustainable ecotourism site based on the Indonesian regulation, ecotourism, and sustainability principles, within the context of the three dimensions of sustainable development; economy, environment, and society. The Kite Diagram of Sustainability Analysis presents that the sustainability status of all the used dimensions classified as sustain. The overall sustainability status of ecotourism is sustainable with the index 76.49. The most sustainable dimension is education and recreation, while the least is the participation dimension.

The results of this study confirmed that within the parameters of the study, the forest maintained an ecological balance, socio economic advancement, and cultural preservation. Ecotourism has high attraction potentials for both tourist and local businesses while impacting less on the culture, environment, and the traditional practices of the Balinese people. Land-use change is dominantly the problem associated with ecotourism destinations. The surrounding environment attracts businesses due 
to the high attraction potential of the ecotourism destination, which often results to change in land-use from farming (rice production) to business centres, hotels, restaurants, etc. There is a high rate at which local people lose lands to national and international investors.

\section{Acknowledgement}

I acknowledge the support and assistance of Susan Stage and Nick Burgoyne. Big thanks to IDB.

\section{REFERENCES}

[1] Čerović, S., M. Knežević, V. Matović, I. Brdar. 2015. The contribution of tourism industry on the GDP growth of Western Balkan Countries. Industrija 43(3), 497-15.

[2] Hakim, L., J. E. Kim, and S. K. Hong. 2009. Cultural landscape and ecotourism in Bali Island, Indonesia. Journal of Ecology and Environment 32(1), 1-8.

[3] Hakim, L. 2008. Planning for nature-based tourism in East Java: recent status of biodiversity, conservation, and its implication for sustainable tourism. ASEAN Journal on Hospitality and Tourism 7, 155167.

[4] Sutawa, G. K. 2012 . Issues on Bali Tourism development and community empowerment to support sustainable tourism development. Procedia Economics and Finance 4, 413-422.

[5] Hill, J. L. and R. A. Hill. 2011. Ecotourism in Amazonian Peru: Uniting tourism, conservation and community development. Geography 96(2), 75-85.

[6] Isaacs, J. 2000. The limited potential of ecotourism to contribute to wildlife conservation. Wildlife Society Bulletin. 28. $10.2307 / 4617284$.

[7] Coria, J. and E. Calfucura. 2012. Ecotourism and the development of indigenous communities: The good, the bad, and the ugly. Ecological Economics 73, 47-55.

[8] Worrld Wildlife Fund. 2005. The arguments for protection series: beyond beliefs, linking faiths and protected areas to support biodiversity conservation. World Wide Fund for Nature, UK. 